\title{
Growth rates in Thoroughbred foals
}

\author{
Z. A. Jelan', L. B. Jeffcott'2, N. Lundeheim ${ }^{3}$ and M. Osborne ${ }^{4}$ \\ 'Department of Animal Science, Universiti Pertanian Malaysia, Serdang, Malaysia \\ ${ }^{2}$ Faculty Board of Veterinary Medicine, University of Cambridge, England \\ ${ }^{3}$ Department of Animal Breeding, Swedish University of Agricultural Science, Uppsala, Sweden \\ 4Kildangan Stud, Monasterevin, Ireland
}

\begin{abstract}
Summary
Data of 798 Thoroughbred horses foaled in 1988 to 1992 in Co. Kildare, Ireland were examined in a study to provide detailed information on a range of parameters on normal growth and development from birth to 20 months of age (onset of training). Based on average body weight gain, the pattern of growth in Thoroughbred horses destined for flat racing could be divided into four phases; each was characterized by markedly different growth rate. However, this pattern was not observed for withers height where the rate gradually declined following an initial rapid growth in the first 6 months of age. Differences of body weight and height at the withers between normal and DOD-affected horses were not significant $(P \geq 0.05)$. These investigations appear to indicate that the body weight and withers height and their rates of growth were not critical in causing developmental skeletal probiems. This is contrary to most other studies which suggested that the rate of growth is related to many developmental skeletal abnormalities in young Thoroughbred horses.
\end{abstract}

keywords: $\quad$ growth, Thoroughbred, foal, bodyweight, height

\section{Wachstumsraten bei Vollblutfohlen}

Daten von 798 Vollblutpferden, die zwischen 1988 und 1992 in Kildare, Irland, geboren wurden, standen für die Analyse des Wachstums und der Entwicklung von der Geburt bis zum 20. Lebensmonat (Beginn des Trainings) zur Verfügung. Aufgrund der durchschnittlichen Zunahmen konnte der Wachstumsverlauf bei Vollblütern, die Flachrennen bestreiten, in vier Phasen unterteilt werden, die durch deutliche Unterschiede in der Wachstumsrate charakterisiert waren. Diese Differenzen bestanden jedoch nicht für die Widerristhöhe, deren Zunahme nach einem initialen schnellen Wachstum in den ersten 6 Lebensmonaten kontinuierlich abfiel. Unterschiede im Körpergewicht und in der Widerristhöhe zwischen Fohlen ohne und mit orthopädischen Entwicklungsstörungen waren nicht signifikant $(P \geq 0.05)$. Diese Ergebnisse scheinen anzudeuten, daß Körpergewicht und Widerristhöhe sowie deren Zunahmen im Hinblick auf die Entstehung orthopädischer Entwicklungsstörungen des Skeletts nicht kritisch sind. Dies steht im Gegensatz zu den meisten anderen Untersuchungen, nach denen bei Vollblutfohlen die Wachstumsrate in Beziehung stand zu den verschiedenen entwicklungsbedingten Skelettanomalien.

Schlüsselwörter: Wachstum, Vollblüter, Fohlen, Körpergewicht, Höhe

\section{Introduction}

In view of the interest to produce quality yearlings for sales and a necessity to begin training and competitive life at a relatively young age, breeders emphasise selection pressure for early physical maturity. Rapid growth plus large and muscular body types characterise the selection criteria for breeding horses (Watkins 1991). Expression of the growth potential of these horses is substantiated by a high nutritional input based mainly on concentrate feed. A high nutritional input which resulted in rapid growth have been said to predispose the growing horses to several forms of developmental orthopaedic disease (DOD) (Stromberg 1979; Hintz and Kallfelz 1981; Wright and Pickles 1991). However, the feeding guidelines for expressing optimum whilst minimising the risk of developmental skeletal disorders is not understood. Growth of a foal should produce a smooth curve, being steepest in the first few months of age and gradually levels after about 2 years of age (National Research Council 1989). Today, most breeds of horses achieve approxi- mately $90 \%$ of their mature weight by 18 months of age (Frape 1986; Jackson and Pagan 1993).

The ultimate withers height of most horses is reached early in life through rapid extension and maturation of the long bones of the limbs. The Thoroughbreds attain about 80,90 and $95 \%$ of the mature height at the withers at 6,12 and 18 months old respectively (Hintz 1978). When adequately fed, Thoroughbred horses can achieve 95\% of their eventual bone growth by one year of age (Hintz 1980). Most breeds attain approximately $90 \%$ of their final withers height by 12 months of age (Frape 1986; Jackson and Pagan 1993).

This paper reports on a retrospective examination of growth records from birth to onset of training in a group of Thoroughbred horses from a well managed stud farm. The purpose of this study was to obtain information on optimal growth rate which can form an acceptable growth standard and to compare with the growth of those with DOD. 


\section{Materials and methods}

\section{Location and management of foals}

The work described here was based on data of Thoroughbred horses from a stud farm in Co. Kildare, Republic of Ireland. Growth of these foals from birth to the onset of training were monitored at monthly intervals. Foaling season took place in mid-January to June and foals were weaned in July, September and November when they were approximately 5-6 months old. They were generally stalled at night and turned out during the day in the paddocks in summer. Most yearlings were turned out daily for 6-7 hours. Occasionally, yearlings were kept in the paddock all day and night when the weather was favorable. All yearlings returned to the stall for veterinary care and feeding. In spring and autumn, they spend less time in the paddocks and usually kept indoors during cold and wet weather. Weanlings and yearlings were supplemented with 2 and $4 \mathrm{~kg} /$ day supplement (mixture of oats, soya, maize, gowla and bran) respectively. However, the amount given also depended on body condition and weight.

\section{Management of data}

The investigation material comprised data of 798 foals born between 1988 to 1992. The population comprised 456 colts $(57 \%)$ and 342 fillies (43\%). The breakdown of data according to year of foaling in 1988,1989, 1990, 1991 and 1992 was 104 , $145,188,181$ and 180 foals respectively.

\section{Measurement of body weight}

The first measurement was recorded on the day of foaling. This was occasionally delayed if the foals were born weak or unable to suckle. Monthly body weight was measured at the beginning of the month using a digital electronic read-out platform scale (AVERY 2000 UK; accuracy 0.5\%) which was permanently mounted on the floor of all yards. Weighing was recorded to the nearest $0.5 \mathrm{~kg}$ and was done in the morning before the horses were fed or let out into the paddocks.

\section{Measurement of height at the withers}

The height at the withers was measured using a standard measuring stick. This was done at the highest point of the withers (immediately above the spinous process of the $5^{\text {th }}$ thoracic vertebra) with the horse standing on a level concrete floor and in a square position.

\section{Diagnosis of $D O D$}

Information on DOD (epiphysitis, osteochondrosis and wobbler syndrome) was obtained through the weekly individual record of each horse from birth to the time it entered training. There were 103 cases which were confirmed by radiology. This was detected between 4 to 17 months of age.

\section{Statistical methods}

The statistical analyses and handling of data were performed on SAS program package (SAS Institute Inc., 1988). The material was divided into groups according to the age at recording. Age groups were constructed at intervals of 30 days from birth to 600 days old. Recording made at the interval of 15 days of the expected normal point (e.g. 30 days) were included in that group of recordings. In cases where a horse had more than one observation in that group, the observations that were closest to the expected normal point were included in the statistical analyses.

For each group the traits were pre-corrected by single analysis of variance, according to a model which included the effects of sex, birth year and the regression on actual measuring age. The individual residual deviations after this pre-adjustment were thereafter used for testing the differences between groups of horses. The level of significance used was 0.05 .

\section{Results}

\section{Average body weight and daily weight gain (ADG)}

The patterns of body weights and ADG of the horses are shown in Figure 1a. The trend from birth to 20 months old is represented by a smooth and almost linear curve which tapers as the body weight gradually increased. The gradient of the curve was steepest in the first 9 to 10 months followed by reduction in growth rate until 13 to 14 months of age. The initial linear growth pattern was observed again until 15 to 16 months of age before starting to plateau.

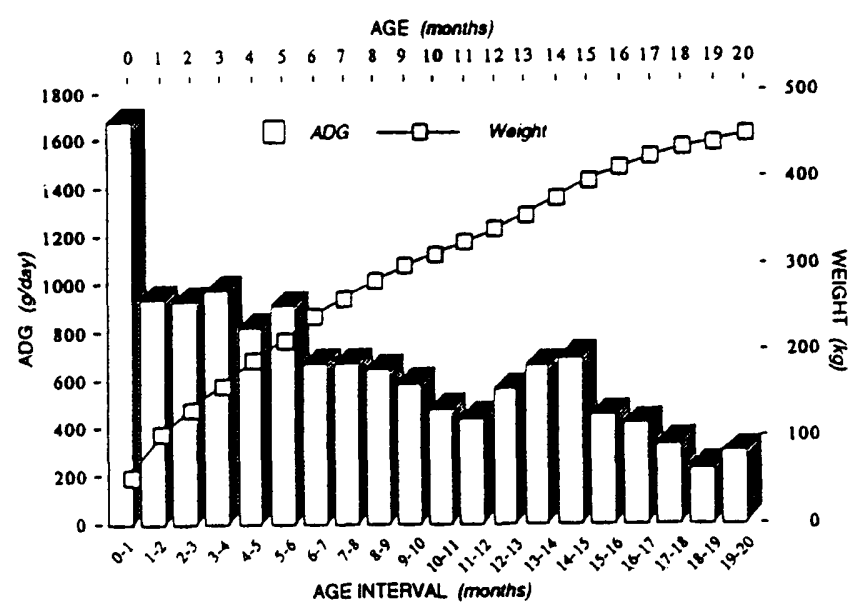

Fig. 1a:Body weight and ADG curves in Thoroughbred foals.

Körpergewicht und tägliche Gewichtszunahme (ADG) be Vollblutfohlen

The overall pattern of ADG from birth to 20 months old could be described in 4 phases; birth to 1,1 to 12,12 to 15 and 15 to 20 months of age. The most rapid growth occurred in the first month where the ADG was in excess of $1.6 \mathrm{~kg} /$ day. In the second phase, the ADG ranged between 0.9 to $1.0 \mathrm{~kg} /$ day between 1 to 4 months old and gradually decreased to 0.5 $\mathrm{kg} /$ day at 11 to 12 months of age. The third phase occurred between 12 to 15 months of age. The ADG increased from 0.5 to $0.7 \mathrm{~kg} /$ day. In the last phase (15 to $19-20$ months old), ADG gradually decreased from 0.7 to approximately $0.2 \mathrm{~kg} /$ day.

The percentage change in body weight from birth is summarised in Table 2. The average birth weight was $53.3 \mathrm{~kg}$, which was approximately $12 \%$ of the body weight $(450 \mathrm{~kg})$ at 20 months old. The average body weight of foals at weaning (6 months old) and by 12 months old were 240.5 and $340 \mathrm{~kg}$ res- 
pectively. The yearlings attained $91(411 \mathrm{~kg})$ and $96.5 \%(433.5$ $\mathrm{kg}$ ) of the eventual weight at 20 months.

Table 1 shows the body weight at bi-monthly intervals, the degree of changes from birth and the percentage of weight attained relative to the weight at onset of training. The change in body weight from birth to 2 months old was $147 \%$ and increased to $744 \%$ by 20 months of age. The increase from birth to weaning was $351 \%$ and in excess of $530 \%$ by 12 months of age. normally attained at 20 months of age. The height attained at 6 and 12 months was approximately 132 and $146 \mathrm{~cm}$, which corresponded to approximately 85 and $94.5 \%$ respectively, of the height at 20 months old.

Body weight and ADG in normal and DOD affected horses

The body weight in normal and DOD-affected horses are illustrated in Table 3. The affected horses were generally heavier

Tab. 1: Bi-monthly body weight $(x \pm S)$, percentage increase from birth and rate of change relative to body weight at the onset of training $(450 \mathrm{~kg})$

Körpergewicht $(x \pm s)$, Zunahme (in \% des Körpergewichtes) sowie relativ bezogen auf das Gewicht zu Trainingsbeginn $(450 \mathrm{~kg})$ in \%

\begin{tabular}{|l|c|c|c|c|c|c|c|c|c|c|c|}
\hline AGE (month) & 0 & 2 & 4 & 6 & 8 & 10 & 12 & 14 & 16 & 18 & 20 \\
\hline Weight (kg) & $\begin{array}{r}53.5 \\
\pm 3.8\end{array}$ & $\begin{array}{r}131.5 \\
\pm 15.5\end{array}$ & $\begin{array}{r}188.5 \\
\pm 19.0\end{array}$ & $\begin{array}{r}240.5 \\
\pm 17.5\end{array}$ & $\begin{array}{r}280.0 \\
\pm 31.0\end{array}$ & $\begin{array}{r} \pm 12.0 \\
\pm 23.5\end{array}$ & $\begin{array}{c}340.0 \\
\pm 25.5\end{array}$ & $\begin{array}{c}377.0 \\
\pm 27.7\end{array}$ & $\begin{array}{c}411.0 \\
\pm 29.1\end{array}$ & $\begin{array}{c}434.0 \\
\pm 27.7\end{array}$ & $\begin{array}{c}450.0 \\
\pm 25.5\end{array}$ \\
\hline $\begin{array}{c}\text { Increase from } \\
\text { birth (\%) }\end{array}$ & - & 147 & 254 & 351 & 425 & 485 & 538 & 607 & 671 & 713 & 744 \\
\hline $\begin{array}{c}\text { Relative to wt. } \\
\text { at training (\%) }\end{array}$ & 12 & 29 & 42 & 53 & 62 & 69 & 76 & 84 & 91 & 96 & 100 \\
\hline
\end{tabular}

Average height and rate of growth at the withers

Figure $1 \mathrm{~b}$ shows the average height at the withers of all horses. The height curve was steep in the first 3 months of age whilst the curve beyond this age was sloping gradually until approximately 14 to 15 months of age. The curve began to plateau between 14-15 to 19-20 months old. The gain in height was most rapid ( $8 \mathrm{~cm} /$ month) from birth to 1 month old, but declined to less than $3 \mathrm{~cm} /$ week between 3 to 4 months of age. However, the gain in height between 4 to 6 months peaked to approximately $4 \mathrm{~cm} /$ month and gradually decreased to less than 1 $\mathrm{cm} / \mathrm{month}$ when the foals were between 16 to 20 months old. No noticeable change in height at the withers was observed by 18 months of age.

Percent change in height from birth, at bi-monthly intervals and at the onset of training is shown in Table 2 . The average height at birth $(104.4 \mathrm{~cm})$ was equivalent to $67.4 \%$ of the height they

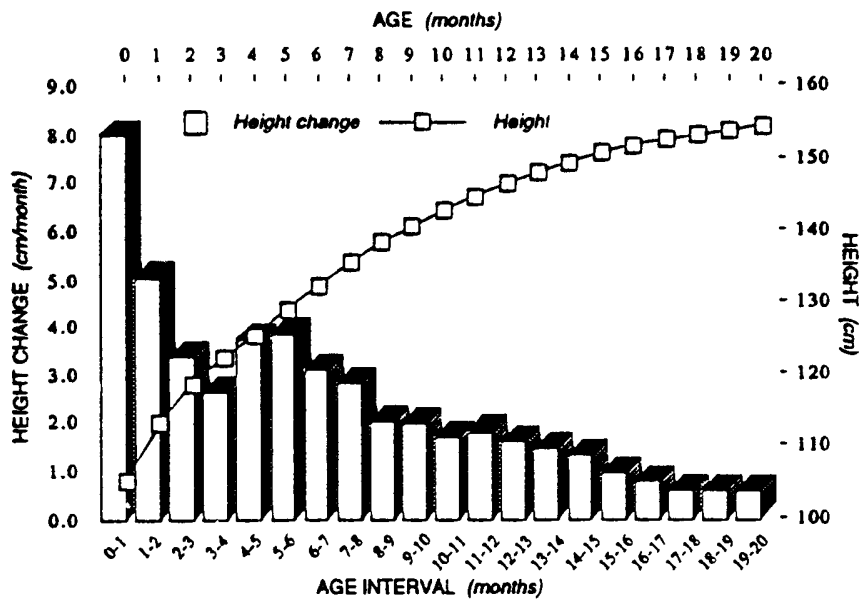

Fig. 1b:Withers height and its rate of change curves in Thoroughbred foals.

Widerristhöhe und deren Wachstumsrate bei Vollblutfohlen than the normal group from 6 through to 12 months of age and at the onset of training (18 months old). However, this difference was not significantly different $(P \geq 0.05)$. At 14 and 16 months old, both groups showed generally similar body weight.

\section{Withers height in normal and DOD affected horses}

Table 3 highlights the withers height in normal and DOD affected horses. There was no significant difference $(P \geq 0.05)$ between both groups at all age intervals measured. However, the normal horses appeared to be taller at the withers at these age intervals.

\section{Discussion}

Studies on growth and development require detailed and sequential monitoring from birth to maturity in a large number of animals. In the Thoroughbred horses, these are not often available due to the nature of the stud management and policy where there are numerous sales and movement of foals from the stud. Growth studies were usually conducted with limited number of horses and may not reflect growth rate under normal conditions. Some of the earlier studies were conducted by Green (1969; 1976), but these investigations either emphasised growth of matured horses of over 2 years old or were measured at a longer age intervals. However, Hintz (1979) reported growth of 1992 Thoroughbred foals from 1 to 12 months of age during the period 1958 to 1976 . Except between birth to 4 months old, the body weights of these foals were lighter than those born in 1991.

Active growth occurred immediately after birth and gradually decreased as the horse reached approximately 18 months old. Frape (1986) suggested that maximum rate of growth continues until 9 months of age, before declining as adult size and shape were attained. This study demonstrated similar trend of linear body weight curve from birth to approximately 
Tab. 2: Bi-monthly withers height $(x \pm s)$, percentage increase from birth and rate of change relative to its height at the onset of training

Widerristhöhe $(x \pm s)$, Zunahme (in \% der Höhe zur Zeit der Geburt) sowie relativ bezogen auf die Widerristhöhe zu Trainingsbeginn in \%

\begin{tabular}{|l|c|c|c|c|c|c|c|c|c|c|c|}
\hline AGE (month) & 0 & 2 & 4 & 6 & 8 & 10 & 12 & 14 & 16 & 18 & 20 \\
\hline Height (cm) & $\begin{array}{c}104.5 \\
\pm 3.8\end{array}$ & $\begin{array}{r}119.0 \\
\pm 4.0\end{array}$ & $\begin{array}{c}124.0 \\
\pm 3.9\end{array}$ & $\begin{array}{r}132.0 \\
\pm 3.2\end{array}$ & $\begin{array}{c}138.5 \\
\pm 3.2\end{array}$ & $\begin{array}{c}142.5 \\
\pm 3.4\end{array}$ & $\begin{array}{c}146.0 \\
\pm 3.3\end{array}$ & $\begin{array}{c}149.5 \\
\pm 3.4\end{array}$ & $\begin{array}{c}151.5 \\
\pm 3.4\end{array}$ & $\begin{array}{c}153.0 \\
\pm 3.2\end{array}$ & $\begin{array}{c}154.5 \\
\pm 3.4\end{array}$ \\
\hline $\begin{array}{l}\text { Increase from } \\
\text { birth (\%) }\end{array}$ & - & 14.0 & 19.0 & 26.5 & 32.5 & 36.5 & 40.0 & 43.0 & 45.5 & 46.5 & 48.0 \\
\hline $\begin{array}{l}\text { Relative to ht. } \\
\text { at training (\%) }\end{array}$ & 67.5 & 76.5 & 80.0 & 85.5 & 89.0 & 92.0 & 94.5 & 96.5 & 98.0 & 99.0 & 100 \\
\hline
\end{tabular}

Tab. 3: A retrospective study on average body weight and withers height $(x \pm s)$ in normal and DODaffected Thoroughbred horses

Retrospektive Studie über durchschnittliches Körpergewicht und Widerristhöhe $(x \pm S)$ bei Vollblutfohlen ohne und mit orthopädischen Entwicklungsstörungen

\begin{tabular}{|l|c|c|c|c|c|c|}
\hline \multirow{2}{*}{$\begin{array}{l}\text { AGE } \\
\text { (month) }\end{array}$} & \multicolumn{2}{|c|}{$\begin{array}{c}\text { Number of horses } \\
\text { Normal }\end{array}$} & With DOD & \multicolumn{2}{|c|}{ BODY WEIGHT (kg) } & \multicolumn{2}{|c|}{ WITHERS HEIGHT (cm) } \\
\hline 4 & 47 & 19 & $190.0(2.4)$ & $185.6(3.1)$ & $125.6(0.6)$ & $125.3(0.8)$ \\
\hline 6 & 215 & 50 & $239.9(1.3)$ & $244.3(2.4)$ & $133.3(0.2)$ & $132.7(0.5)$ \\
\hline 8 & 451 & 76 & $279.3(0.2)$ & $284.9(0.4)$ & $138.6(0.2)$ & $137.1(0.4)$ \\
\hline 10 & 573 & 97 & $311.5(0.8)$ & $314.0(2.1)$ & $142.7(0.1)$ & $141.3(0.3)$ \\
\hline 12 & 560 & 83 & $339.6(0.9)$ & $341.7(2.3)$ & $146.2(0.1)$ & $145.8(0.3)$ \\
\hline 14 & 527 & 78 & $376.8(1.0)$ & $375.8(0.3)$ & $149.3(0.1)$ & $149.3(0.3)$ \\
\hline 16 & 581 & 90 & $411.0(1.1)$ & $410.0(2.9)$ & $151.7(0.1)$ & $151.6(0.3)$ \\
\hline 18 & 416 & 62 & $433.1(1.4)$ & $436.0(3.9)$ & $153.3(0.1)$ & $152.8(0.3)$ \\
\hline
\end{tabular}

8 to 9 months of age. The rate of ascent of the curve slowed progressively until 13 to 14 months old. Body weight curve rose rapidly again, before it began to plateau at 16 to 18 months of age (Figure 1a). In general, the potential for rapid body weight gain persists until about 15 to 16 months of age, when they achieved approximately $90 \%$ of the weight relative to the weight at the onset of training (Table 1). The rate of growth of nursing foals is related to the amount of milk produced by their mares. The milk yield largely depends on the nutritional status of the mares, mainly the availability of good quality pasture and supplementary feeds. The milk output of mares has been shown to be 149, 139 and $163 \mathrm{~g} / \mathrm{kg}$ body weight 0.75 at 11,25 and 39 days post-partum respectively (Oftedal, Hintz and Schryver 1983). In Ireland, rapid growth coincided with spring and early summer, but slower growth rate was observed when the foals experienced their first winter and after weaning.

The monthly body weight of a foals should produce a smooth curve which is steepest after birth and gradually levels off after 2 years of age (Williams and Pugh 1993). A smooth growth curve can be achieved by appropriate nutritional management which provides an appropriate and optimum nutritional input during rapid growth. This is essential because this study has shown that average body weight increased by 8 folds from birth $(53.5 \mathrm{~kg}$ ) to 20 months of age $(450 \mathrm{~kg}$ ) (Table 1).
The monthly variations in ADG after weaning declined steadily as availability and quality of pasture decreased. However, the age between 11 to 15 months old was the only phase from birth to onset of training of the yearlings, when ADG curve increased. This corresponded with greater accessibility to nutrients from the pasture where much of the growth of horses in the stud normally took place. During the grazing season, the crude protein content of pasture varies considerably from $110-260 \mathrm{~g} / \mathrm{kg}$ of pasture dry matter (Frape 1986). As the quality of pasture varies with the seasons of the year, it is a normal practice to supplement protein and energy concentrate to yearlings. Improvement in feeding was also aimed to improve physical appearance of foals and yearlings. Some of the foals are sold in autumn of the following year (MacCarthy and Mitchell 1974).

Most yearlings were able to regain body weight that matched the others after a period of slow growth. These Thoroughbreds were managed to produce annual crops of weanlings and yearlings with greater uniformity in body weight and conformation when they first entered training. Monthly weighing of all foals was effectively used as an exercise for this purpose so that they were without physiological age or weight advantage at the start of their racing life.

Height at the withers largely reflects linear growth of the long bones of the forelimbs which increase in length by growth at both ends of the bones (Frape 1986). Maximum growth of bone 
is achieved early in life and maximum height may be achieved by 12 months. These foals were born with an average height equivalent to approximately $68 \%$ of height at the onset of training (Table 2). At 12 months of age, they attained approximately $95 \%$ of height at start of training by rapid monthly increase in the first 2 months of age. If the mature height for the Thoroughbred mare was assumed to be $160 \mathrm{~cm}$ (Willougby 1975), then the foals in this study would attain 83,91 and $96 \%$ of mature height at 6,12 and 18 months of age, respectively. The proportions of height attained are similar to those reported by Hintz et al. (1979). Changes in height were generally small beyond 12 months old.

Large and rapidly growing horses are said to be predisposed to DOD (Stromberg 1979; Hoppe 1984). Osteochondrosis in pigs and broilers tend to be related to body size, but similar suggestion using large data on Thoroughbred horses have not been previously reported. The trend of the body weights did not suggest any obvious differences between normal and DOD affected horses. The difference in average body weight between the both groups at all age intervals measured was $<6 \mathrm{~kg}$. The difference was particularly small $(<3 \mathrm{~kg})$ beyond 10 months of age. The feeding programme of the foals were designed to ensure all horses had a uniform body size and weight for its age. Therefore, a long duration of continuous difference in growth pattern between in the groups was not observed. The rates change in body weight in both groups were gradual and the difference between them was $<0.12 \mathrm{~kg} /$ day throughout the period of study. The horses did not indicate compensatory growth during the period of study. Studies in Swedish Standardbred horses indicated that those with osteochondrosis had a higher ADG and were heavier from birth through to 16 months of age. The difference in the body weight between the normal and affected Standardbred horses was also significantly large $(15-20 \mathrm{~kg})$ between 6 and 16 months of age (Sandgren 1993).

This study did not indicate significant differences in withers height between affected and non-affected horses. This was similarly showed in Standardbred horses by Sandgren (1993) who reported osteochondrosis affected horses were not significantly taller than their unaffected counterparts. The present study did not indicate that body weight and height and their rates of change have strongly influence the development of DOD in the Thoroughbred horses in this stud.

In conclusion, although the data were from one stud, they do provide an important evaluation of growth patterns in well managed Thoroughbreds. These data are series of measurements (at least 5) of individual horses over several years, from birth to 20 months old. This information can form guidelines for a normal growth pattern of Thoroughbred horses from birth to the onset of training. The expense of research of nutrition and skeletal studies in horses is always high, but the rewards of such an investigation in terms of academic knowledge and practical application for the horse industry are enormous.

\section{References}

Frape, D. L. (1986): Growth of the horse. Equine Nutrition And Feeding. Longman Scientific \& Technical, England. pp. 156-168.

Green, D. A. (1961): A review of studies on the growth rate of the horse, $\mathrm{Br}$. vet. J. 117, 181-191.

Green, D. A. (1969): A study of growth rate in Thoroughbred foals. Br. vet. J. $125,539-546$.

Green, D. A. (1976): Growth rate in Thoroughbred yearlings and two year olds. Equine vet. J. 8, 133-134.

Hintz, H. F. (1978): The growth rate of horses. Proc. Am Ass. Equine Practnr. 24, 455-459.

Hintz, H. F. (1979): A review of recent studies on the growth of horses. Calif. Vet. 33, 17-19.

Hintz, H. F. (1980): Growth in the horse. In. Stud Manager's Handbook. Vol. 16, pp. 59-66, Agriservices Foundation, California.

Hintz, H. F. and Kallfelz, F. A. (1981): Some nutritional problems of horses. Equine vet. J. 13, 183-186.

Hintz, H. F., Hintz, R. L. and Vleck, L. D. van (1979): Growth rate of Thoroughbreds. Effect of age of dam, year and month of birth, and sex of foal. J. Anim. Sci. 48, 480-487.

Hoppe, F. (1984) Radiological investigations of ostechondrosis dissecans in Standarbred Trotters and Swedish Warmblood horses. Equine vet. J. 16, 425-429.

Jackson, S. G. and Pagan, J. D. (1993): Developmental orthopedic disease. Multiple causes-no sure cures. J. Equine vet. Sci. 13, 9-11.

Koterba, A. M. (1990): Prematurity. II. Intrauterine growth retardation. In. Koterba, A..M. (ed.), Equine Clinical Neonatology, pp. 69, Lea \& Febiger, Philadelphia.

MacCarthy, D. and Mitchell, J. (1974): A study of growth rate in Thoroughbred foals and yearlings. Ir. J. Agric. Res. 13, 111-117.

National Research Council (1989): Nutrient requirements of horses. $5^{\text {th }}$. edn. National Academy Press, Washington D.C.

Oftedal, O. T., Hintz, H. F. and Schryver, H. F. (1983): Lactation in the horse: milk composition and intake by foals. J. Nutr. 113, 2096-2106.

Pugh, D. G. and Schumacher, J. (1993): Feeding and nutrition of brood mares. Compend. cont. Educ. Pract. Vet. 15, 106-115.

Pugh, D. G. and Williams, M. A. (1992): Feeding foals from birth to weaning. Compend. cont. Educ. Pract. Vet. 14, 526-533.

Sandgren, B. (1993): Osteochondrosis in the tarsocrural joint and osteochondral fragments in the metacarpo/metatarsophalangeal joints in young Standardbreds. Dissertation, Faculty of Veterinary Medicine, Swedish University of Agricultural Sciences, Uppsala, Sweden.

Stromberg, B. (1979): A review of the salient features of osteochondrosis in the horse. Equine vet. J. 11, 211-214.

Trotter, G. W. and MCl/wraith, C. W. (1981): Osteochondrosis dissecans and subchondral cystic lesions and their relationship to osteoshondrosis in the horse. J. Equine vet. Sci. 1, 157-162.

Watkins, J. P. (1991): Osteochondrosis/physitis. In. Colahan, P. T., Mayhew, I. G., Merritt, A. M. and Moore, J. N. (eds.), Equine Medicine and Sugery. Vol. II, 4th ed., pp. 1308-1316, American Vet. Publ., California.

Wright, I. M. and Pickles, A. C. (1991): Osteochondritis dissecans (OCD) of the femoro-patellar joint. Equine vet. Educ. 3, 86-93.

Williams, M. A. and Pugh, D. C. (1993): Developmental orthopaedic disease: Minimising the incidence of a poorly understood disorder. Compend. Cont. Educ. Pract. Vet. 15, 859-872.

Willoughby, L. D. and Hintz, H. F. (1981): A survey of feeding practices at two Thoroughbred racetracks. Equine Nutr. Physiol. Soc. Symp. 7 , 136-140.

Z. A. Jelan

Department of Animal Science Universiti Pertanian Malaysia 43400 UPM Serdang, Selangor Malaysia

\section{N. Lundeheim}

Department of Animal Breeding

Swedish University

of Agricultural Science

Uppsala

Sweden

\section{B. Jeffcott}

Faculty Board of Veterinary Medicine University of Cambridge

Madingley Road

Cambridge CB3 OES

England

\section{Osborne}

Kildangan Stud

Monasterevin

Co. Kildare

Ireland 